\title{
MYCETOZOA \\ FOUND IN THE GOWER PENINSULA, SEPTEMBER 19 to OCTOBER 2, 1916.
}

\author{
By Gulielma Lister, F.L.S.
}

The following list of Mycetozoa includes the species found during the Swansea Foray in expeditions taken in the southeast of the Gower Peninsula, and also those obtained by two of the members during the previous week in the neighbourhood of Llangennith, at the extreme north-west of the Peninsula.

In the latter district four types of hunting ground favourable for Mycetozoa presented themselves, viz., mixed woods of oak, ash, sycamore, and a few larches; heaps of hedge clippings; dead stems of gorse and bramble lying under the shelter of a stone wall, among grass and bracken; and old straw heaps spread around a cluster of stacks in a meadow.

The first expedition of the Swansea Foray, September 28th, was to the mixed woods and park-land of Sketty Park and the Clyne Valley. Almost continuous rain was unfavourable to collecting many Mycetozoa, but twelve species were obtained. September 29 was fine, with showers. We were conducted across Smear Moor to a plantation of young oak, birch, spruce, and Scotch fir; thence over moorland by Saint Iltyd Church to Carey's Wood, and on to Gower Inn. On September 30, a brilliant day, our hunting grounds lay east of Gower proper, in a series of steep, mixed woods, Darran Wood, Stanley Wood and Mountain Pine Wood, near Skewen. On October I we visited Cillibion Plantation, a moist wood of oak, ash, and alder, with scattered pine and spruce, and with undergrowth of rhododendron and bramble, the whole intersected by broad grass rides; later we strolled down Green $\mathrm{Cwm}$ and searched the woods of oak and ash on its slopes. This was by far our most favourable day, both for Fungi and Mycetozoa.

In the accompanying list of the species of Mycetozoa that were observed, the districts in which they were found are indicated by the following abbreviations: $-L .=$ Llangennith; $S .=$ Sketty Park and Clyne Valley; $M .=$ Smear Moor and Carey's Wood; $D .=$ Darran and Stanley Wood; $C .=$ Cillibion Plantation and Green Cwm. 
Ceratiomyxa fruticulosa (Muell.) Macbr. $L$. On fallen oak boughs.

Badhamia utricularis (Bull.) Berk. M., C. Plasmodium only found creeping over Corticium sp.

$B$. panicea (Chev.) Rost. $C$. On dead ivy stems.

Physarum nutans Pers. $L ., S ., M ., D ., C$. Very abundant on dead wood.

$P$. viride (Bull.) Pers. $L$. On fallen oak bough.

$P$. pusillum (Berk. \& Curt.) Lister. L. On hedge clippings.

$P$. bitectum Lister. S. On dead holly leaves.

$P$. cinereum Pers. $L ., C$. On dead thistles, nettles and old straw.

Fuligo septica Gmel. L., D. A few weathered aethalia only seen.

Craterium minutum (Leers) Fries. L., C. On straw, leaves and twigs.

Leocarpus fragilis (Dicks.) Rost. $C$. Found in yellow plasmodium which matured into sporangia indoors.

Diderma hemisphericum (Bull.) Hornem. L. Very abundant on hedge clippings.

$D$. effusum (Schwein.) Morgan. C. On dead leaves.

Diachaea leucopoda (Bull.) Rost. $C$. On dead leaves and twigs.

Didymium difforme (Pers.) Duby. L. Abundant on old straw, hay and hedge clippings.

$D$. complanatum Rost. $L$. On dead bracken stalks among grass.

D. squamulosum (Alb. \& Schw.) Fries. I., S., D. On straw and dead leaves.

D. Clavus (Alb. \& Schw.) Rost. L. On hedge clippings.

$D$. nigripes Fries. $S$, $C$. On holly leaves and pine twigs. Var. xanthopus Lister. L., $D$. On dead leaves.

$D$. melanospermum (Pers.) Macbr. $M ., C$. On pine needles and twigs.

Mucilago spongiosa (Leyss.) Morgan. L., C. On old straw and dead leaves.

Stemonitis fusca Roth. L., S., M., C. On dead wood. Var. confluens Lister. $D$. A large growth with very irregular columellae was found on a stump.

S. flavogenita Jahn. L., S., C. On dead wood and leaves.

$S$. ferruginea Ehrenb. $C$. On dead wood.

S. splendens Rost., var. flaccida Lister. S. A weak form with very slender columellae.

Comatricha nigra (Pers.) Schroet. L., S., M., D. Abundant on dead twigs.

C. laxa Rost. $L ., M$. A robust form with cylindrical sporangia was obtained on old gorse and other twigs. 
C. pulchella (Bab.) Rost. D. On dead oak leaves, mouldy. Lamproderma scintillans (Berk. \& Br.) Lister. L. On hedge clippings.

L. arcyrionema Rost. L. On dead wood. This is the first time the species has been obtained on our forays, and is a new record for Wales. Although widely distributed throughout the Old and New worlds, $L$. arcyrionema is not common in the British Isles. In England it has been obtained in Middlesex, Essex, Bedfordshire, Sussex, Norfolk, Yorkshire, Herefordshire, and Cornwall. It has not yet been recorded for Scotland or Ireland.

Enerthenema papillatum (Pers.) Rost. L. On fallen oak branches.

Cribraria rufa (Roth.) Rost. L. On a prostrate larch.

Dictydium cancellatum (Batsch) Macbr. L. On dead wood.

Reticularia Lycoperdon Bull. D., C. Two aethalia were found on stumps.

Lycogala epidendrum (L.) Fries. $L$., S., C. On stumps.

Trichia affinis de Bary. $L$. On dead wood.

$T$. verrucosa Berk. $D$. A single small gathering of this uncommon species was made on dead wood.

$T$. persimilis Karsten. L., S., C. Fairly abundant on dead wood.

T. decipiens (Pers.) Macbr. L., D., C. On stumps.

$T$. Botrytis Pers. M., D. On fallen boughs of oak and pine. Hemitrichia clavata (Pers.) Rost. $C$. On dead wood.

Arcyria cinerea (Bull.) Pers. L., S., M., D., C. Abundant on dead wood, sometimes on dead leaves.

A. pomiformis (Leers) Rost. L., S., M., D. Remarkably abundant on fallen oak boughs.

$A$. incarnata Pers. L., $M$. On dead oak wood.

$A$. denudata (L.) Sheldon. L., $M$.

A. nutans (Bull.) Grev. L., M., D., C. Abundant; in one case large tufts of the mature yellow sporangia were found on a decayed oak branch still attached to the tree, and several feet from the ground.

Perichaena corticalis (Batsch) Rost., C. On dead wood.

Although no specimen of very striking interest was collected, this list of 47 species compares well with those obtained on our previous forays. Wrexham, in 1910 , gave us 44 species of Mycetozoa; Taunton, in I9II, a very dry year, 27 species; Haslemere, in 1913,42 species; Doncaster, in 1911,36 species. The only list that exceeds it is our remarkable Forres record, in 1912, of 81 species. 